\section{Perspectives on American Politics: Domestic and Foreign}

Carol Nechemias

The Pennsylvania State University at Harrisburg

Two of the plenary sessions held jointly by the American Political Science Association and the International Political Science Association had a strong appeal for students of American politics. A large turnout of scholars, both from abroad and from the United States, was present for the session chaired by Thomas E. Mann (Brookings Institution) on the U.S. Presidential Election. At this plenary session three experienced campaign consultants, William Schneider, Greg Schneiders, and John Deardourff, sought to make sense of the Bush-Dukakis contest. The other plenary session, entitled "Foreign Perspectives on the U.S. Polity and Politics," features scholars who not only are not involved in the fray of American politics, but who observe American developments from homelands as diverse as the Soviet Union, Canada, and France. Chaired by Kinhide Mushakoji, this panel included Fedor Burlatsky of the USSR; Anthony King, a Canadian teaching in Great Britain; and Marie-France Toinet of France. Seymour Martin Lipset of Stanford University served as a discussant.

In introducing the panel on the U.S. Presidential Election, Mann noted that first impressions leave one with a view of the current campaign as volatile and trivial. Volatile because of wild swings in mood: the image of the seven dwarves quickly gave way to the emergence of a strong candidate, Mike Dukakis; while the "George Bush is dead" rhetoric two weeks later became "What is wrong with Michael Dukakis?" And the triviality of the issues, from the pledge of allegiance to the "let me introduce you to my family and loving wife. . ." threatens to drown out any discussion of matters like the underclass, Soviet-American relations, or macroeconomics.
Nonetheless, Mann felt that second impressions generate more serious views of the campaign. He challenged the panelists to examine the candidates' electoral strategies within the context of the state of the economy, the nature of public opinion, the political geography of the American electorate, and the various stages of the political cycle.

Arguing that the Democrats have tried to break with losing patterns, William Schneider contended that the party has nominated the "same ticket three times." This ticket, coupling a northern liberal Protestant presidential nominee with a northern liberal Catholic vice-presidential candidate, occurred in 1968, 1972, and 1984, and each time the Democrats garnered roughly $40 \%$ of the vote. Now, with a liberal northern Greek Orthodox running with a southern Baptist, the Democrats stand a better chance of securing a winning formula.

The Democirats also have avoided another pitfall: the tendency to nominate a "preacher Democrat." According to Schneider, Stevenson, McGovern, and Mondale "all would have become preachers if they had not become politicians."

These "preacher Democrats" have a fatal flaw. From the public's perspective they are not tough enough and will be patsies for special interests and for the Russians. Schneider did point to Jimmy Carter as an exception, a preacher candidate who was able to gain election by exploiting the national mood in 1976-the clamor for morality and integrity. But, as Schneider noted, Carter failed to offer leadership.

For Schneider the key to electoral victory involves reading the national mood. Winning candidates sense what the public is not getting from the incumbent, what the public wants, and sells it to them. After Eisenhower, for example, there was a sense of lethargy, an unease stemming from Sputnik, and a desire for action and youth. In 1968 it was order, with Nixon promising to bring us together; in 1976. the theme of morality; and in 1980, strong principles and leadership.

But what can the Democrats sell now? William Schneider suggested the management theme, arguing that "after eight years of Ronald Reagan. Americans have 
had enough of vision." Hence a Dukakis talking about competence and professionalism rather than ideology.

Schneider also identified President Reagan's popularity as another key factor. Reagan's popularity is up to $60 \%$, after having declined to $50 \%$ in the wake of Irangate. The President's standing helps account for why Bush is doing well.

Regarding specific issues, Schneider stressed that Dukakis should not talk about issues, or "people will discover he is a liberal." The public assumes he is for change, and that is enough. With an electorate balanced between continuity and change, the Democrats must focus on the future.

On foreign policy, Schneider saw a significant Bush advantage. He asserted that a foreign policy crisis in the Mideast, or a highly publicized event before the election, like the release of hostages or a Gorbacher meeting, would raise Reagan's popularity even further and boost Bush's chances for the presidency.

With respect to the issue of what difference it makes who wins, Schneider stated that Bush would be in a weak leadership position. Bush would be blamed for anything that goes wrong and will, in all likelihood, be facing a Democratically controlled Congress, with Jim Wright and a new majority leader "sharpening their knives with Bush."

Dukakis, on the other hand, can blame the Republicans for the first $1-2$ years of his administration and enjoy considerably more cooperation from Congress. Yet like the other candidates, Dukakis does not have a passionately committed base of support, the kind of support Ronald Reagan possesses. When he is wrong, or his policies do not work, his supporters will desert him.

Schneider characterized Dukakis as a problem solver, with an approach to poli- tics that assumes that there is a technical or a right answer for problems. A problem solver as president will be effective only as long as the solutions work.

In accounting for the volatility of the polls, John Deardourff stated that "while lots of political scientists are interested in the election, the public is not." For most Americans, the election has not yet begun. And for most people, according to Deardourff, the election is a 36-hour process.

For Deardourff, the election will answer two crucial questions. Will the Reagan Democrats go home? And which of the two contenders is the safer agent of change? The Bush campaign must not allow the election to be a choice between the past and the present. Most of the voters want a change of direction. Hence, the convention rhetoric that "we are the change."

To ensure victory, Deardourff argued that Bush must focus the campaign on foreign policy, an area in which he will look more presidential than Dukakis. He must also make Dukakis a liberal candidate running a liberal campaign. And finally, the Republicans must keep the economy from collapsing before the election. According to Deardourff, the Republicans are living on borrowed time: any bad economic news will adversely affect Reagan Democrats.

Many Reagan Democrats have not benefitted from economic recovery and are apprehensive. Deardourff described this group as being selectively pro-government. Reagan Democrats see government as potentially helpful to them, in areas like housing, day care, and medical assistance. But their cultural values are in tune with Ronald Reagan's and with the post. 1980 George Bush. They are for capital punishment, for prayers in the public schools, for a strong national defense, and for the pledge of allegiance.

\section{New Section Added to 1989 Annual Meeting Program}

Program chairman Nelson W. Polsby has named Paul Allen Beck to the 1989 Annual Meeting Program Committee to head a Section 34 on Electoral Behavior and Public Opinion. See Association News for details. 


\section{Perspectives on American Politics}

Deardourff predicted that the 1988 campaign will be the first to target voters state-by-state, to localize campaigning by creating and distributing ads for specific locations. With the growing level of sophistication, a TV ad can be produced and run in the same day. The possibilities for changing the message and for tailoring the message to particular localities will be exploited as never before. He foresees a close election, with each side having 130-135 electoral votes and the rest up for grabs.

According to Greg Schneiders, objective conditions give Bush a significant advantage. There is peace and prosperity; low inflation, low unemployment, and a thaw in Soviet-American relations. In these circumstances, tertiary issues like drugs and day care come to the top. It is these peripheral issues Dukakis is trying to exploit, while Bush will talk mainly about peace and prosperity. In Schneiders' view, Dukakis faces an uphill battle to shift attention to his issues.

In the area of candidate image, however, Schneiders thinks Dukakis has the edge. Polls have shown that the public views Bush as wishy washy. There is a trust issue, with people not sure what he stands for. Schneiders stressed that Dukakis needs to raise doubts about Bush's leadership by engaging in negative campaigning. Dukakis must convince the public that peace and prosperity will be more safely preserved in the hands of the Democrats.

In the discussion that followed, Mann pointed out that historical precedents are at odds. On the one hand, the electorate in this century has always turned to the other party after eight years of one party in power. On the other hand, economic models and presidential popularity favor the Republicans.

The images projected by the candidates evoked further comment, with Mann observing that the last Republican president born to wealth and privilege was William Howard Taft and that "Bush reminds Reagan Democrats why they used to be Democrats." The addition of Quayle, "a young, tough conservative who got where he got through connections, also makes a cultural statement."

The role of Jackson aiso drew comment. The panelists believed that Jackson might help in targeted areas but could hurt in the national effort. The question was raised as to whether one party could continue to win elections without the support of any blacks and to the racial undertone to the campaign. It was further noted that jackson supporters form the single most coherent voice on the American left, and that if Dukakis loses, they may reel that it is now their turn to field a presidential candidate.

\section{Foreign Perspectives}

The plenary session on "Foreign Perspectives on the American Polity and Politics" offered more general assessments of the American political scene. Fedor Bur. latsky argued that there are pieces of positive experience in every civilization and that democracy reflects the accumulation of human values over time. In a recent article on Soviet political reform, he drew on universal experience by commenting favorably on institutions like a working parliament, a strong presidency, a constitutional court, a division of power, and amendments on human rights. Admiration

\section{Nominations Sought for 1989 APSA Awards}

Nominations are invited for the APSA awards to be presented at the 1989 annual meeting in Atlanta. Dissertations must be nominated by departments and submitted by January 15, 1989. Books must be nominated by publishers and submitted by February 1. 1989. Members are invited to nominate individuals for the career awards. Further details may be obtained by writing the national office. 


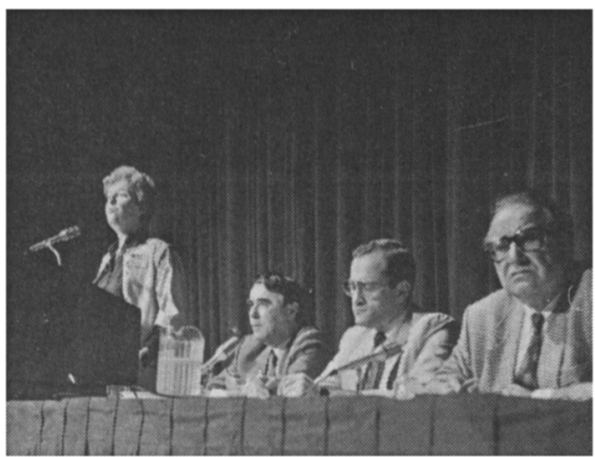

Participants in the IPSA plenary on foreign views of the U.S. polity: Marie-France Toinet (a former APSA Congressional Fellow); Fedor Burlatsky, translator; and Seymour Martin Lipset.

for certain elements of the American political system has influenced his own recommendations concerning Soviet political reform.

On the other hand, Burlatsky found fault with several aspects of American politics. First, he argued that the U.S. polity was not well suited for a dynamic age. The overly slow mechanism of Americn decision-making reminded him of the Brezhnev era in the USSR. He characterized American culture as gnawed away by conservatism and weather-vane leaders.

Secondly, he criticized the American two-party system as a poor shadow of the party systems in Western Europe and Japan, where it is possible to tell party programs apart and where strong social democratic and sometimes communist parties compete. Fur Burlatsky, telling the Republicans from the Democrats is a virtually impossible task.

Burlatsky saw American conservatism as most evident in nuclear policy. Instead of embracing a sharp turn in policy, he noted that the United States, despite the INF Treaty, still emphasizes strengthening American defenses, with nuclear weapons as the principal means of deterrence. Disarmament, even the minimization of warheads ( 100 on each side), is dismissed as utopian. He also complained that getting rid of the image of the Soviet Union as enemy has not gained ground.
In the area of Soviet-American rivalry in the developing countries, Burlatsky accused both the United States and the USSR of messianism, of seeking to impose, respectively, Americanization or Sovietization in the third world. Although both superpowers have had enough bumps on their heads to look and think anew, he questioned whether America was ready for a new approach to regional conflicts.

Anthony King introduced himself as "one of nature's pro-Americans," a Canadian who does not take offense at being taken as an American. He offered "three worries and one non-worry" about the American polity. One problem involves the existence of a large underclass, a phenomenon King regarded as unique to America among the Western nations. The physical and moral degradation of the underclass gives rise to the drug culture and to another aspect of the American condition-much more crime than elsewhere. King wryly asked why conservatives are decrying the drug culture, since handing out free cocaine could provide a useful means of social control. Drugs, having replaced religion as the opiate of the masses, serve to keep the have-nots from attacking the existing social structure. King urged the United States to seek to be inclusive and to develop a welfare state instead of thinking it already has one.

A second worry centered on America's relations with the outside world. According to King, one of the challenges facing the United States involves finding a new-and diminished-role in the world. He offered American action in Lebanon in the 1950s and the 1980s as an illustration of the decline of U.S. influence. American politicians must find a way of managing a transition to a new international role; they must get the style and language right. According to King, failure to do so might provoke an ugly, defensive mood, reminiscent of the Know-Nothings of the 1850s, the Ku Klux Klan, or McCarthyism. He noted that while Americans may be laid-back as a people, they are not as a country. Americans sing the national anthem more than anyone else in the world. Superpatriots, they are largely unaware of the decline in America's ability to influence 
the world.

A third concern focused on signs of incipient economic decline in America. Here, King pointed to the trade deficit as the key indicator. He argued that since 1788 there have been three great empires made up of a relatively small number of people in a small geographic area who turned outward. These three people-the British, the Russians, and the Americanssecured a large protected market for home producers, a market largely free from competition. He asserted that in all three cases economic difficulties stemmed from the empire itself: protected markets are bad for home producers and the end of protection brings economic troubles. Another period of transition looms, with the gap between American rhetoric and American realities growing ever wider.

King's "one non-worry" involved a celebration of American political institutions. He described the American polity as astonishingly stable - "the greatest political success story in human history." "He accounted for this success by pointing to three factors: (1) the presence of a "large number of political geniuses" like Madison and Jefferson in the last part of the 18th century; (2) the presence of a virtually empty empire in which to expand; and (3) the presence of the principle of periodicity in the Constitution.

King singled out the principle of periodicity, the review of American political elites every two or four years, for special praise. He called it a "wonder and astonishment" that even during periods of high stress like 1862 and 1864, elections were held. He noted with confidence that 100 years from today, in the year 2088, on the first Tuesday after the first Monday in November, we can expect that an American president will be elected. And he asked. "How many countries can you say that about?"
Marie-France Toinet broke with orthodoxy by arguing that a strong national American state has existed since 1787/ 1788. Indeed, she contended that the American state was the first modern, strong state in the Western world. For Toinet, there is no American exceptionalism in terms of a weaker, less centralized state in comparison with other Western democracies. The American government's role in the economic development of the country, from the days when the federal government held $80 \%$ of the land to its current role in public spending, support the proposition that a strong, centralized, pervasive state has existed-but its presence has never been readily acknowledged. Indeed, Toinet regards the extent of state intervention evident in decisions regarding prayer in public schools, contraception, sexual behavior, and reapportionment not only as impressive but as unthinkable in the French unitary state, with its allegedly greater powers vis-a-vis local government and society.

Seymour Martin Lipset acknowledged the value of commentaries about America by foreigners who see things that Americans cannot see. He agreed with Burlatsky that the United States and the USSR are both messianic, political nations. He took issue, however, with the contention that the two parties are the same. Lipset stated that the two parties only "pretend they are the same," but that an examination of, say, the types of people who would get appointed to the National Labor Relations Board under a Republican rather than a Democratic president readily explains labor's support for the Dukakis candidacy. Indeed, Lipset asserted that there is as much cleavage in the American party system as there is in other countries with social democratic or socialist parties.

In assessing King's analysis, Lipset

\section{Correction}

In the summer 1988 PS, p. 725, under "APSA Research Grantees Announced for 1988," the name of Carole Jean Uhlaner, University of California, Irvine, should be added to the members of the Selection Committee who reviewed and evaluated the grant applications. 
pointed to American religiosity as a factor generally overlooked by intellectuals seeking to explain the workings of American society. Lipset suggested that the high levels of belief in God and in church going reinforces messianism and affects foreign policy. He pointed to the connection between the Protestant tradition of following one's conscience and a uniquely American phenomenon-the presence of a strong anti-war movement during every war except World War II. Americans may be patriotic, but that patriotism has not necessarily meant "our country right or wrong." This moralistic element also has contributed to the tendency to see our enemies as satan, as an evil empire.

With respect to the underclass, Lipset observed that King's comments parallel statements made about the Irisn in the 1850s. He argued that the underclass stems from an open immigrant society and has repeatedly been a source of violence.

Lipset also took issue with King's views on the American economy. He contended that the economy is more open now than in the past, and he counts on a large and continuing influx of immigrants to "refurbish" the United States and keep us from getting soft.

On the question of state power, Lipset discounted Toinet's stress on the longterm existence of a strong, centralized state by citing the recurrent threats to secede before the Civil War and the tendency for members of Congress, during the first 75 years of American history, to leave office, not because they were defeated, but because they preferred serving in state legislatures than in Washington, DC.

\section{Mansbridge Receives Second APSA Award for Why We Lost the ERA}

Jane Mansbridge of Northwestern University shared the Victoria Schuck award for the best book published in 1986 or
1987 on women and politics with Rebecca E. Klatch of the University of California, Santa Cruz. Klatch was recognized for her book. Women of the New Right. Mansbridge's Why We Lost the ERA had previously shared the 1987 Gladys M. Kammerer Award for the best political science publication in the field of U.S. national policy.

Ambassador Jeane J. Kirkpatrick, and Jeffrey $H$. Birnbaum and Allan S. Murray of the Wall Street Journal were also among those honored at the APSA's 84th annual meeting. John W. Ryan of Indiana University presented Kirkpatrick, former U.S. Ambassador to the United Nations, with the Hubert $\mathrm{H}$. Humphrey Award for notable public service by a political scientist. Birnbaum and Murray were presented with the Carey McWilliams Award by Nelson Polsby of the University of California, Berkeley. Birnbaum and Murray's book, Showdown at Gucci Gulch: Lawmakers, Lobbyists and the Unlikely Triumph of Tax Reform, represented a major journalistic contribution to the understanding of politics.

Kenneth Shepsle of Harvard University and Barry Weingast of the Hoover Institution shared the first Heinz Eulau Award for the best article published in The American Political Science Review in the previous year. Shepsle and Weingast were recognized for their article, "The Institutional Foundations of Committee Power."

The Woodrow Wilson Foundation Award for the best book published in the United States during 1987 on government, politics, or international affairs was awarded to Robert Gilpin of Princeton University for his book. The Political Economy of International Relations.

David Baldwin of Columbia University presented the Gladys $M$. Kammerer Award for the best publication in 1987 on U.S. national policy to Dennis F. Thompson of Harvard University for his book, Political Ethics and Public Office.

The Ralph !. Bunche award for a scholarly work exploring the phenomenon of ethnic and cultural pluralism was received by Earl Black of the University of South Carolina and Merle Black of the University of North Carolina for their book, Politics and Society in the South. 